Available online http://www.lumenpublishing.com/journals/index.php/lumenlaw ISSN: 2284 - 5968 (print), ISSN: 2284 - 5968 (electronic)

\title{
Logos Universality Mentality Education Novelty Section: Law
}

2017, Volume V, Issue 2, December, pp. 67-92

\section{Deontological Perspectives on Police Activity}

\section{Larisa Ionela PAŞNICIUC}

https://doi.org/10.18662/lumenlaw.5

Covered in:

CEEOL, Index Copernicus, Ideas RePeC, EconPapers, SocioNet, HeinOnline 


\title{
Deontological Perspectives on Police Activity
}

\author{
Larisa Ionela PAŞNICIUC 1
}

\begin{abstract}
In a state of law, Police are among the most important institutions, with the aim of protecting the citizen. Although this structure appeared a long time ago, it did not cease to develop with the society and adapt to the needs of the current times. Romanian police represent the link between the state and the society, and democracy is not possible without the help of this institution. Respect for citizens' rights and freedoms is a priority for the Romanian Police, and all its actions are for the sole purpose and interest of the society. The partnerships between citizens and police help to exert their job responsibilities and improve the relationship between them.
\end{abstract}

Keywords: police, deontological perspectives, police activity, trust.

\section{Introducere}

Într-un stat de drept, Poliția se numără printre cele mai importante instituții, având ca scop protejarea cetățeanului. Cu toate că această structură a apărut cu mult timp în urmă, nu a încetat să se dezvolte odată cu societatea şi să se adapteze nevoilor vremii.

Poliția Română reprezintă liantul dintre stat şi societate, democrația nefiind posibilă fără ajutorul acestei instituţii. Respectarea drepturile şi libertățile cetățenilor reprezintă o prioritate pentru Poliția Română, iar toate acțiunile efectuate de aceasta sunt numai în scopul şi interesul societății. Partenerialele care iau naştere între cetățeni şi organele de poliție ajută la exercitarea atribuțiilor de serviciu şi la îmbunătăţirea relaţiei dintre acestea.

Având în vedere că Poliția Română acționează în interesul cetățenilor, aceasta organizează misiuni cu scopul de a combate criminalitatea în serie şi de a preveni săvârşirea infracțiunilor. Astfel, se creează un mediu sigur pentru societate, cetățenii exercitându-şi drepturile şi libertățile fără a fi îngrădiți.

Puterea cu care polițistul este investit în momentul în care a dobândit statutul de polițist, nu poate fi exercitată în interes personal, acesta având în vedere ocrotirea interesului public.

\footnotetext{
${ }^{1}$ Faculty of Law and Administrative Sciences, Stefan cel Mare University from Suceava, Romania, larisaionela07@yahoo.com.
} 
Personalul care lucrează în această instituție are dreptul în anumite cazuri prevăzute de lege să îngrădească anumite drepturi şi libertăți ale cetăţenilor. Acest fapt urmăreşte pedepsirea celor care încalcă legea şi incercarea de a garanta tuturor drepturile constituționale.

Datorită faptului că Poliția Română are un rol foarte important în dezvoltarea statului şi, totodată, a cetățenilor, imaginea pe care aceasta o are formată contează când vine vorba de încrederea pe care acesta i-o oferă. Odată cu încrederea, se vor naşte anumite relaţii de cooperare care vor fi benefice pentru ambele părți.

Imaginea Poliției Române se formează prin comportamentul polițiştilor şi modul în care aceştia îşi îndeplinesc atribuțiile de serviciu. Odată ce un cetățean a avut parte de o experiență neplăcută, în sensul că un polițist nu 1-a tratat aşa cum ar fi trebuit, acesta va ezita să mai apeleze la serviciile prestate de această instituție, iar încrederea va scădea drastic. Un astfel de caz poate fi foarte uşor generalizat de către societate, datorită faptului că cetățenii urmăresc şi analizează de cele mai multe ori eşecurile apărute, iar de rare ori îi interesează sau țin cont de ceea ce se întâmplă în favoarea lor.

Deoarece este importantă imaginea Poliției Române în ochii cetățenilor, s-a considerat a fi oportună o cercetare pentru a se stabili dacă societatea mai are încredere în această instituție (INSCOP Research, 2015a; 2015b; 2016).

Structura prezentei lucrări este alcătuită din două părți. Prima dintre acestea se bazează pe partea teoretică, fiind alcătuită din trei capitole, iar cea de-a doua, pe partea practică, o anchetă cu privire la încrederea pe care o au cetățenii în Poliția Română.

Pentru a putea înțelege care sunt scopurile unei instituții şi pentru a înțelege cum funcționează aceasta, trebuie analizate originea şi modul de funcționare al acesteia. Datorită acestui fapt, lucrarea de faţă începe printr-un scurt istoric al Poliției Române, pentru a se observa dacă au avut loc schimbări drastice în ceea ce o priveşte sau dacă imaginea acesteia a fost afectată odată cu trecerea timpului.

Poliția Română are la bază câteva legi precum Legea nr. 218 din 2002 privind organizarea şi funcționarea, dar şi Codul de etică şi deontologie al polițistului. Urmând aceste dispoziții cu strictețe, s-a considerat a fi necesară o scurtă analiză a acestor acte. Astfel se poate înțelege care sunt obiectivele principale ale acesteia, în ce mod îşi desfăşoară activitatea profesională organele de poliție. 


\section{I.1. Scurt istoric al activităţii polițieneşti în România}

Poliția Română, ca orice altă instituție, nu a existat dintotdeauna, iar datorită acestui fapt se consideră a fi necesară o analiză pe parcurs, din punct de vedere istoric, al apariției acesteia.

Poliția a luat naştere odată cu constituirea primelor oraşe, inclusiv numele acesteia derivând de la cuvântul „,polis” care definea în limba greacă oraşul. Încă din vremurile îndepărtate, Poliția a fost văzută din prin ochii poporului ca fiind statul, personalul care îndeplinea atribuțiile administrative fiind numiţi „,polițişti”. Dezvoltarea statelor a dus la separarea Poliției de celelalte segmente care aveau ca scop serviciul public şi a devenit mult mai puternică făcându-şi simțită prezența în viața cetățenilor.

În jurul secolului al XIV-lea a luat naştere funcția de mare vornic, acesta trebuind să îndeplinească anumite atribuții de natură administrativă, militară şi judecătorească. Conform atestărilor istorice, această funcție a fost creată în T,ările Române, iar autoritatea era exercitată la nivel de principat.

$\mathrm{Cu}$ trecerea timpului, numărul atribuțiilor a început să crească, iar pentru a le îndeplini, marele vornic avea nevoie de persoane în subordinea sa, aceştia din urmă fiind numiţi vornici. La începuturi, marele vornic trebuia să asigure paza curții domneşti, iar mai apoi, supraveghea străinii care păşeau pe teritoriul său, hanurile care îşi desfăşurau activitatea în interiorul principatului, dar şi oamenii care locuiau în acele zone. Astfel, au început să se contureze anumite atribuții care se întâlnesc şi în prezent în fişa postului unui polițist.

Poliția Română a fost menționată încă din timpul lui Neagoe Basarab şi al lui Mihai Viteazul odată cu înființarea unei instituții numită Agie (Poliția Română, 2014). Aceasta a fost creată înaintea Poliției, dar atribuțiile pe care le avea erau de natură polițienească. Agia era prezentă în cele două capitale care existau în acele vremuri, şi anume: Bucureşti şi Iaşi. Fiecare instituție prezentă în aceste două oraşe avea în frunte un agă, denumire provenită din limba turcă. Mihai Sturzi, în timpul domniei sale, a continuat dezvoltarea acestei autorități prin organizarea pazei Capitalei, dar şi cu introducerea unor acte de identitate. Mai mult, în timpul domniei lui Mihai Sturzi a apărut şi o reglementare ce privea portul armelor.

Datorită domniilor fanariote care au existat între anii 1711 şi 1821, instituția Agiei a ajuns la apogeul dezvoltării sale, acest fapt având loc datorită domnitorilor din acea perioadă care au creat numeroase reforme în diferite domenii. De asemenea, structura Bucureştiului a avut de suferit, aceasta fiind divizată în plăşi conduse de către zapcii. La scurtă vreme 
teritoriul țării urma să fie organizat în județe, acestea fiind administrate de ispravnici.

În anul 1821, Tudor Vladimirescu a hotărât ca persoanele care au ca atribuții de serviciu atât menținerea ordinii publice, cât şi apărarea proprietății cetățenilor, trebuie să fie scutite de anumite taxe şi impozite. Mai mult, atribuțiile poliției au fost extinse odată cu adoptarea Regulamentelor organice. După domnia acestuia a apărut şi prima lege a Poliției, aceasta fiind numită „Alcătuirea poliției şi îndatoririle sale”. Dispozițiile cuprinse în acest document identificau atribuțiile acestei instituții şi poate fi considerat prima lege care prevedea modul în care este organizată Poliția, de asemenea, şi primul document de acest tip din spaţiul românesc.

Revoluția de la 1848 a adus şi o reorganizare a poliției (Druga \& Stirbu, 2016, p. 418) prin care a fost instituită instituția şefului poliției Capitalei, regăsindu-se în subordinea acesteia Guardia municipală.

Domnitorul Ghica Vodă, la data de 9 iunie 1850 a elaborat „Cronica polițienească”, numărându-se printre cele mai complete legi care făceau referire la organizarea şi funcționarea Poliției Române. Această lege a apărut pentru prima dată în Moldova, dar mai apoi a fost adoptată şi în Muntenia, acest fapt având loc datorită unificării administrative a celor două teritorii. Până la acel moment, domnitorul Barbu Ştirbei nu a neglijat acest aspect, creând anumite reforme de natură polițienească.

„Cronica polițienească” era alcătuită din 158 de articole, acestea având ca obiect reglementarea atribuțiilor ,înaltei poliții” şi „obişnuitei poliții". Acest moment a marcat constituirea primei structuri centrale a cărei obligaţii făceau referire la organizarea şi coordonarea activităţilor poliţieneşti. Odată cu anul 1859 a apărut şi Prefectura Poliției Capitale.

De-a lungul timpului, competența organelor de poliție şi-a lărgit granițele prin diferite acte. Primul pas a fost făcut prin adoptarea Legii de organizare a poliției de către Alexandru Ioan Cuza la data de 4 noiembrie 1860. Aceasta a fost urmată de Legea lui Vasile Lascăr care datează din anul 1903 şi, nu în ultimul rând, Legea pentru organizarea poliției generale a statului care a apărut la data de 8 iulie 1929. Datorită acestei noi legislații, raporturile pe care poliția le avea la acea vreme cu alte structuri din cadrul statului au fost mult mai clar reglementate.

Legea de reorganizare a Poliției creată de către ministrul de interne Vasile Lascăr, îşi propunea asimilarea polițiştilor în cadrul magistraţilor. Scopul a fost acela de a crea o instituție solidă care să vină în ajutorul statului şi să reuşească să asigure ordinea publică pentru ca toate activitățile să se 
desfăşoare după cum sunt prevăzute. Astfel, s-a încercat o izolare a poliției pentru ca aceasta să nu mai fie influențată de către politicieni sau de către alți factori care $\mathrm{i}$-ar putea afecta eficacitatea.

Încă din acele timpuri oamenii de seamă şi-au dat seama că un stat nu se poate dezvolta dacă nu are o structură care să-i asigure şi să protejeze ordinea şi liniştea publică. Fiind foarte preocupat de acest aspect, Vasile Lascăr, în timpul unui discurs în faţa Parlamentului a ridicat o întrebare a cărui ecou a rămas până în zilele noastre: „Cum voiți domniile voastre să se dezvolte o societate şi să se întărească un stat, dacă nu e mai întâi garantată de ordinea publică şi siguranța interioară?" (Biroul Protocol Inspectoratul General al Poliției Române, 2012, p. 8).

Take Ionescu, în anul 1913, pune accentul pe stabilitatea persoanelor care îndeplinesc atribuțiile polițieneşti şi decide că aceştia din urmă pot fi revocați din funcția pe care o dețin doar după ce se va lua o hotărâre de către Comisia Disciplinară.

Marea unire care a avut loc la data de 1 decembrie 1918 nu a uşurat situația din acea vreme. Constantin Argetoianu a trebuit să se ocupe de reorganizarea administrativă, reformele sale vizând şi teritoriile noi care au fost ataşate tării. Poliția a trebuit să fie instituită şi în celelalte zone, mai întâi în Basarabia şi Bucovina în anul 1918, iar mai apoi Transilvania în anul imediat următor.

Legea de Organizare a Poliției Generale a Statului avea să fie adoptată în anul 1929, iar aceasta prevedea o împărţire bine organizată şi definită, astfel fiind create trei direcții centrale: administrativă, judiciară şi de siguranţă. In ceea ce priveşte organele exterioare, acestea erau alcătuite de: Prefectura Poliției Municipiului Bucureşti, Inspectoratele regionale, Chesturile de poliție, Polițiile de reşedință, Comisariatele şi Detaşamentele de Poliție.

Prin Decretul - Lege nr. 2.370 din vara anului 1940 a fost creată Direcția Generală a Poliției şi Siguranței Statului, care era alcătuită din fosta Direcție Generală de Poliție, Corpul de Jandarmi, şi nu în ultimul rând, instituția care a luat naştere în anul 1859, Prefectura Poliției Capitalei. După numai două luni, intrând in funcție generalul Ion Antonescu, Decretul Lege a fost abrogat, astfel reinstituindu-se forma de organizare anterioară (Biroul Protocol Inspectoratul General al Poliției Române, 2012, p. 9).

Miliția a luat naştere în anul 1949 odată cu Decretul nr. 25 din 23 ianuarie 1949, iar la câteva decenii, odată cu Revoluția din România din iarna anului 1989, s-a reînființat Poliția Română prin Decretul - Lege nr. 2 din 27 decembrie 1989. Nevoia reglementării competențelor acestei instituții a 
condus la apariția Legii nr. 26 din 18 mai 1994 şi a Legii 218 din 23 aprilie 2002.

Decretul din anul 1949 a creat Direcția Generală a Miliției, astfel desființând Poliția şi Jandarmeria. Nevoia de claritate în ceea ce priveşte atribuțiile Miliției a dus la naşterea deciziei numărul 43, prin care s-au clarificat sarcinile acestei noi instituții. Tot în acelaşi an au fost instituite Trupele de securitate, acestea îndeplinind unele îndatoriri care anterior se aflau în sarcina Jandarmeriei, dar nu au fost asimilate de către Miliție.

Cu toate că poliţia a avut un rol important în dezvoltarea tării, această instituție a fost privită cu alți ochi de către unii cetățeni, aceştia susţinând faptul că poliția a ajutat le menținerea regimului comunist de până la 1989 (Biroul Protocol Inspectoratul General al Poliției Române, 2012, p. 11).

Pentru a se asigura respectarea drepturile cetățenilor, dar şi siguranța persoanelor, Poliția Română a cunoscut mai multe transformări după anul 1990. De asemenea, acestea s-au datorat şi modificărilor care au avut loc în acea perioada imediat următoare a Revoluției din anul 1989. Schimbările au avut în vedere şi drepturile protejate de către legislația internaţională şi de tratatele internaționale la care România este parte.

Potrivit art. 1 din Legi nr. 218 din 2002 privind organizarea si funcționarea Politiei Romane, „Politia Romana face parte din Ministerul de Interne si este instituția specializata a statului, care exercita atribuții privind apărarea drepturilor si libertarilor fundamentale ale persoanei, a proprietarii private si publice, prevenirea si descoperirea infracțiunilor, respectarea ordinii si liniştii publice, in condițiile legii”" (Legea nr 218/ 2002).

Legislația cu privire la drepturile şi libertățile omului se află într-o continuă dezvoltare, iar datorită faptului că Poliția Română are ca scop apărarea şi asigurarea exercitărilor acestora, şi legile care precizează organizarea şi funcționarea acestei structuri vor trebui să se adapteze schimbărilor apărute.

Instituția Poliției Române a fost într-o continuă dezvoltare, dar niciodată nu a trecut pe locul doi interesele generale ale cetățenilor, încercând să fie liantul dintre aceştia şi instituțiile statului, ajutând astfel la crearea unui stat democrat.

\section{II.2. Cadrul normativ de funcţionare a Politiei Române}

România a elaborat mai multe legi de-a lungul timpului referitoare la atribuțiile polițistului, dar şi la modul de organizare şi funcționare a Poliției Române. Majoritatea normelor au fost adoptate după începerea tratatelor 
privitoare la aderarea României la Uniunea Europeană. Reorganizarea organelor polițieneşti a fost o necesitate contemporană, fiind nevoie să existe o concordanţă între reglementările europene şi cele la nivel național.

Legea nr. 218/2002 privind organizarea şi funcţionarea Poliţiei Române, împreună cu Legea nr. 360/2002 privind Statutul polițistului, au constituit „,repere fundamentale pentru Poliția Română din prezent” (Druga \& Stirbu, 2016, p. 419), clarificând şi stabilind anumite aspecte referitoare la funcționarea acestei structuri (Torje, 2015). De asemenea, s-a pus accentul şi pe polițist şi pe cariera acestuia, nu numai pe atribuțiile generale ale Poliției Române.

Datorită evoluției societăţii româneşti, legislația internă a fost nevoită să se adapteze dispozițiilor legale internaționale, punând în concordanță activitatea desfăşurată de către polițiştii de pe teritoriul României, cu a celor din afara granițelor. Astfel au luat naştere noi structuri care au avut ca scop combaterea criminalității şi supravegherea acestuia. Mai mult, s-a născut un interes în legătură cu modul în care este percepută Poliția Română de către cetățeni, încercându-se creşterea nivelului de încredere pe care o au aceştia în organele de poliție şi în munca pe care o depun atât în timpul serviciului, cât şi în afara acestuia (Ştefan, 2013).

\section{II.2.1 Legea nr. 218 din 23 aprilie 2002 privind organizarea şi funcţionarea Poliției Române}

\section{Dispozitii generale}

Poliția Română (Legea nr 218/ 2002, Art. 1) este o structură a Ministerului de Interne a cărei atribuții au ca scop ,apărarea drepturilor şi libertăților fundamentale ale persoanei, a proprietății private şi publice, prevenirea şi descoperirea infracțiunilor, respectarea ordinii şi liniştii publice în condițiile legii’" (Legea nr 218/ 2002, Art. 1). Această dispoziție este prezentă chiar în primul articol al Legii, acest fapt punând în evidența importanța exercitării corecte a atribuțiilor de către personalul din cadrul Poliției Române.

Activitatea Poliției Române nu a putut rămâne nedefinită, aceasta trebuind reglementată. Art. 2 al prezentei legi specifică faptul că activitatea acestei instituții este un serviciu public specializat, iar realizarea acestuia are în vedere atât interesul persoanei cât şi interesul comunităţii. Mai mult, Poliția Română trebuie ca prin activităţile pe care le desfăşoară să vină în sprijinul instituției statului, având la bază doar legea. De asemenea, pentru ca acțiunile Poliției Române să conducă la un rezultat pozitiv, aceasta trebuie să 
coopereze nu numai $\mathrm{cu}$ instituțiile statului, ci şi $\mathrm{cu}$ organizaţiile neguvernamentale, persoanele fizice şi juridice, dar nu trebuie să depăşească limitele prevăzute de lege.

Organizarea Poliției Române va tine cont atât de împărțirea administrativ-teritorială (Legea nr 218/ 2002, Art. 4, Alin. 1) a țării, cât şi de specificul unor sectoare ale economiei naționale sau al unor obiective economice sociale. Pentru a se putea înființa o unitate de poliție este nevoie de un ordin al Ministrului de Interne.

\section{Structura organizatorică}

Poliția Română este o instituție alcătuită din mai multe structuri (Druga \& Stirbu, 2016, p. 421) şi anume: Inspectoratul General al Poliției Române, unități teritoriale, instituții de învăţământ şi alte unităţi necesare (Legea nr 218/ 2002, Art. 5).

Structura centrală este reprezentată Inspectoratul General al Poliției Române, unitate atât cu personalitate juridică, cât şi competență teritorială generală. Printre atribuțiile acestei structuri se numără cele de conducere, îndrumare şi controlare a secțiilor de poliție care sunt aflate în subordine, dar şi investigarea şi cercetarea infracțiunilor care prezintă un grad ridicat de gravitate. Pe lângă acestea, Inspectoratul General al Poliției Române poate exercita şi alte atribuții, dar cu condiţia ca acestea să fie încadrate în competenţa sa prin lege.

Inspectorul general este persoana calificată care poate conduce Inspectoratul General al Poliției Române, acesta având posibilitatea de a fi numit de către Primul-ministru prin actul de decizie. Innainte de această procedură, trebuie să existe o propunerea a Ministrului de Interne care a trecut pe Corpul Naţional al Poliţiştilor şi a fost admisă ulterior.

Dispozițiile emise de către inspectorul general al Inspectoratului General al Poliției Române sunt obligatorii pentru personalul care se află în subordinea acestuia. În timp ce aceste acte sunt în curs de elaborare, pentru a se încadra în normele legale, este necesară consultarea Corpului Național al Poliţiştilor şi Consiliul (Consiliu Superior).

\section{Unitati teritoriale din subordinea Inspectoratului General al Politiei Romane}

În Municipiul Bucureşti există Direcția generală de poliție care are personalitate juridică, fiind condusă de către directorul general, acesta din urmă fiind ajutat de adjuncții din subordine. 
La nivel de județ sunt instituite inspectorate de poliție, aceste unități având şi ele la rândul lor personalitate juridică. Conducerea acestora este efectuată de către un inspector-şef, care este ajutat în exercitarea atribuțiilor de serviciu de către adjuncți (Legea nr 218/ 2002, Art. 12).

Persoanele care se află pe posturile de conducere ale acestor unități teritoriale, directorul general şi inspectorii-şefi, sunt numiţi în funcție de către Ministrul de Interne. De asemenea, şi eliberarea acestora din exercitarea atribuţiilor este făcută prin ordinul aceluiaşi ministru. Candidații sunt propuşi de către inspectorul general al Inspectoratului General al Poliției Române, după ce, în prealabil, a fost consultat atât Corpul Naţional al Polițiştilor, cât şi prefectul.

Având în vedere structura capitalei, au fost constituite unități de poliție a sectoarelor, acestea regăsindu-se în cadrul Direcției generale de poliție a Municipiului București. La rândul său, fiecare sector are propriile secții de poliție, numărul acestora nefiind unul la întâmplare, ci stabilit prin ordinul Ministrului de Interne. Pentru a se putea determina numărul secțiilor de poliție al fiecărui sector trebuie avute în calcul mai multe criterii precum: întinderea teritorială a sectorului, numărul de cetățeni care locuiesc în acea circumscripție şi importanţa obiectivelor atât economice cât şi sociale şi politice care există.

Atât în rândul municipiilor, cât şi în rândul oraşelor se pot înființta poliții municipale şi orăşeneşti. De asemenea, în municipii pot exista secții de poliție. La nivelul zonei rurale, comunele au posturi de poliție, iar în cazul celor cu sate şi cătune disperate, există birourile de poliție. Cele din urmă menționate pot fi create doar prin respectarea criteriilor prevăzute la art. 13 alin. (2) din Legea nr. 218 privind organizarea şi funcționarea Poliției Române.

În ceea ce priveşte prevenirea şi combaterea infracționalității, pot fi create unități în structura Poliţiei Române care să aibă acest obiectiv.

\section{Autoritatea teritorială de ordine publică}

Autoritatea teritorială de ordine publică are rol consultativ şi este organizată atât la nivelul Municipiului Bucureşti, cât şi la fiecare județ de pe teritoriul țării. Această unitate îşi desfăşoară activitatea numai în interesul comunităţii (Legea nr 218/ 2002, Art. 17). Autoritatea teritorială de ordine publică are anumite atribuții, care sunt reglementate de art. 18 din Legea nr. 218 din 2002. Autoritatea trebuie să prezinte propuneri care au ca scop soluționarea unor sesizări a căror obiect sunt drepturile şi libertăţile fundamentale ale omului. De asemenea, aceasta nu numai face propuneri, ci organizează şi consultări referitoare la siguranţa persoanei şi a ordinii 
publice, care ar fi prioritățile. Un important punct de vedere este adus în dezbatere de către membrii comunităților locale, această categorie fiind una dintre cele mai apropiate de viaţa pe care cetățenii o au într-o anumită zonă. În fiecare an, această autoritate are obligația de a întocmi un raport (anual) în care se analizează eficiența activităţilor desfăşurate de către unităţile de poliție, aceste date fiind făcute publice.

In ceea ce priveşte competența autorităţii teritoriale de ordine publică, aceasta nu există în cazul problemelor de tip operativ ale poliției. În timpul exercitării atribuțiilor cu care a fost învestită, autoritatea teritorială de ordine publică emite hotărâri, dar acestea au doar un caracter de recomandare.

Cheltuielile (Legea nr 218/ 2002, Art. 20) efectuate pentru Municipiul Bucureşti vor fi suportate din bugetul capitalei, iar în cazul celor din teritoriu, acestea vor fi achitate din bugetele județului în speță.

\section{Raporturile dintre poliţie şi autorităţile administraţiei publice locale}

Pentru a se menține o bună legătură între instituții, iar ca acțiunile să fie pozitive, trebuie să existe o relație strânsă de colaborare între unitățile teritoriale de poliţie şi „prefecții, autorităţile administrației publice locale, autoritățile judecătoreşti, serviciile publice descentralizate ale ministerelor si ale celorlalte organe centrale, precum si cu reprezentanți ai comunităţii”" (Legea nr 218/ 2002, Art. 22).

Legătura (Legea nr 218/ 2002, Art. 24) trebuie să existe între unitățile teritoriale de poliție şi consiliile locale, primării, pentru a se putea pune în executare, în limitele legii, hotărârile sau dispozițiile emise de către acestea.

Pentru ca atribuțiile poliției să fie îndeplinite cu succes şi să fie eficiente, se pot încheia anumite protocoale între autoritățile administrației publice locale şi cele de poliție. Acest fapt se poate întâmpla numai în anumite cazuri şi este obligatoriu ca instituțiile între care se încheie aceste protocoale să fie de comun acord. În cazul în care se descoperă că poliția nu şi-a îndeplinit întocmai atribuțiile stabilite prin protocolul încheiat, administrația publică poate sesiza organul superior de poliție cu scopul de a se deschide o anchetă sau de a se investiga faptele săvârşite sau cele care au fost omise.

\section{Atribuțiile Politiei Romane}

Poliția Română prezintă mai multe atribuții, cele principale fiind enumerate în Legea nr. 218 din 2002, la articolul 26. 
Una dintre cele mai importante atribuții pe care le are Poliția Română este apărarea vieții omului, fiind un aspect care stă la baza oricărei națiuni şi este tratat cu un mare interes de către articolele de specialitate internaţionale. De asemenea, libertatea persoanelor este un alt aspect ce a fost dezbătut la nivel internațional, existând mai multe acte care interzic îngrădirea acestui drept. Nici celelalte drepturi legitime ale cetățenilor nu rămân neapărate, Poliția Română depunând toate diligențele posibile pentru ca fiecărei persoane să nu îi fie îngrădite drepturile.

Menținerea ordinii şi liniştii publice (Manta, 2016, p. 617) intră tot în atribuțiile Poliției Române, acest lucru facilitând respectarea şi asigurarea atât a libertății fiecărei persoane, cât şi siguranța cetățeanului. pentru a se menține ordinea şi liniştea publică, Poliția Română trebuie să fie capabilă la orice moment să identifice anumite acțiuni care ar putea punte în pericol viaţa şi să le şi contracareze. Protejarea proprietății private face parte tot din atribuțiile Poliției Române, această unitate având în vedere nu numai ocrotirea proprietății publice.

Poliția Română va colabora cu unitățile de jandarmerie, le va oferi acestora informațiile necesare pentru menținerea sau chiar şi restabilirea ordinii şi liniştii publice. Această situație apare în special atunci când se desfăşoară mitinguri sau alte tipuri de manifestări care au loc în public.

Pentru a se putea descoperi sau neutraliza anumite dispozitive pirotehnice care au ca scop vătămarea corporală a cetățenilor, Poliția Română va colabora şi cu alte instituții prevăzute de lege ca fiind competente în asemenea situații. În acelaşi fel se va proceda şi dacă dispozitivul ar putea provoca anumite daune atât proprietății publice cât şi celei private sau dacă va tulbura ordinea publică.

Detectivii privați nu se pot organiza şi funcționa sub forma unei societăți decât dacă au fost avizaţi de către Poliția Română. Acest fapt este valabil şi în cazul firmelor de pază şi protecție sau gărzilor de corp, Poliția Română având obligația să le controleze potrivit legii.

Un rol important joacă Poliția Română în prevenirea şi combaterea infracțiunilor, realizând astfel diverse activităţi, dar, în acelaşi timp, ocupându-se şi de strângerea informaţiilor necesare. Printre cele mai întâlnite infracțiuni care se urmăresc a fi combătute se numără cele de corupție şi de crimă organizată. În cazul în care au fost săvârşite infracțiuni, Poliția Română efectuează activități care au ca scop constatarea şi cercetarea faptelor penale, potrivit competenței instituite de lege. 
În anumite situații prevăzute de lege, Poliția Română trebuie să asigure protecția persoanei care a fost vătămată (Dogru, 2013, p. 194) în cursul săvârşirii unei infracţiuni. Pe lângă aceasta, şi martorul care relatează aspecte importante referitoare la comiterea infracțiunii trebuie avut în vedere şi protejat. Acesta poate fi ameninţat, constrâns să dea o declaraţie falsă organelor judiciare sau chiar vătămat de către suspect sau inculpat (sau de către o persoană angajată de către unul dintre aceştia). Pentru ca un proces penal să se desfăşoare conform legii şi pentru a se aplica toate sancțiunile care sunt necesare, trebuie să existe un raport de cooperare între instanţă şi Poliția Română, altfel neputându-se pune în practică anumite soluții.

Poliția Română prin personalul pe care îl are în subordine poate atât constata săvârşirea unor abateri, cât şi aplicarea unor sancțiuni contravenționale, toate aceste aspecte fiind prevăzute de lege.

Datorită naturii atribuțiilor de serviciu ale magistraţilor, şi aceştia împreună cu familiile lor trebuie protejați de către Poliția Română în anumite situații în care este pusă în pericol atât viaţa, cât şi integritatea corporală sau bunurile acestora.

Unele persoane încearcă să se sustragă (Druga \& Stirbu, 2016, p. 420) din cadrul urmăririi penale sau nu doresc să execute pedeapsa, Poliția Română trebuie să efectueze anumite activități prin care să le depisteze şi să le prezinte organelor competente. În această situație se află şi persoanele dispărute, polițiştii încercând prin metodele pe care le au la îndemână găsirea acestora.

Având în vedere că migrația este un subiect care a luat amploare în ultima vreme pe plan internațional, Poliția Română trebuie să prevină, dar să şi combată migrația ilegală, existând anumiți paşi care vor fi urmați în urma depistării unor persoane care îndeplinesc acest criteriu.

Pentru a ajuta magistrații să ajungă la decizia corectă, Poliția Română, prin structurile din alcătuirea sa, foloseşte diferite mijloace tehnico-ştiințifice pentru cercetarea probelor şi a locului în care au fost săvârşite infracţiuni. Probele ce sunt recoltate de la faţa locului vor fi analizate de către specialişti în laboratoare pentru a putea furniza cât mai multe informații posibile cu scopul aflării adevărului.

În ceea ce privește materialele radioactive şi nucleare, Poliția Română controlează, potrivit legii, regimul acestora. În această situaţie se regăsesc şi substanțele toxice şi stupefiantele, dar şi alte obiecte sau materii care, potrivit legii, sunt supuse autorizării. 
Traficul de pe drumurile publice este supravegheat de către persoanele din subordinea Poliției Române, iar pentru îmbunătățirea acestuia este nevoie de o relație de cooperare cu autoritătile publice sau alte instituții. De asemenea, polițiştii au îndatorirea să verifice starea tehnică a autovehiculelor care circulă pe drumurile publice, dar să şi inițieze măsuri prin care să îi educe pe ceilalți conducători care participă la trafic.

Poliția Română este cea care, prin organele sale abilitate, controlează legalitatea stabilirii domiciliului, sau în alte cazuri, a reşedinţei cetăţenilor români sau a celor străini care s-au stabilit teritoriul României.

Cazierul judiciar este eliberat de Poliția Română, iar baza de date le serveşte acestora cu privire la numărul de persoane care au fost cercetate penal, condamnate sau asupra cărora au fost înființate anumite măsuri cu caracter penal.

La nivel naţional, Poliția Română analizează şi cercetează infracționalitatea din România, iar în urma raporturilor propune desfăşurarea unor activități cu scopul de a preveni comiterea altor infracțiuni (Rotaru, 2013, p. 19). Dacă aceste măsuri sunt aprobate de administraţia publică locală sau centrală, Poliția Română are datoria de a colabora (Niță, 2012, p. 20) cu aceste instituții şi de a încerca sprijinirea acestora în vederea efectuării activităților de natură preventivă. De asemenea, colaborarea se va desfăşura şi cu privire la organizațiile neguvernamentale şi a instituțiilor de învăţământ. Pentru ca efectul să fie unul scontat, se vor crea legături şi cu structuri din alte state sau instituții internaționale.

Pe lângă aceste atribuții menționate, Poliția Română exercită şi alte atribuții, doar dacă acestea sunt prevăzute de lege.

Organele de cercetare penală sunt polițişti desemnați prin dispoziție de către inspectorul general al Inspectoratului General al Poliției Române.

\section{Personalul Poliţiei Române}

Potrivit Legii nr. 218 din 2002, personalul care face parte din cadrul Poliției Române este format din ,polițişti, alți funcționari publici şi personal contractual" (Legea nr 218/ 2002, Art. 29).

Prin statutul polițistului au fost specificate drepturile şi îndatoririle ale unui polițist din cadrul Poliției Române. Referitor la personalul contractual, acesta îşi desfăşoară activitatea sub imperiul reglementărilor din domeniul muncii (legislația muncii), numai dacă legea în vigoare nu dispune altfel. 


\section{Drepturile şi obligațiile polițistului}

Polițistul, odată cu atribuțiile pe care le primeşte atunci când este numit în funcție, are anumite drepturi şi obligații care sunt prevăzute de lege.

Pentru a putea dovedi calitatea şi funcția pe care o exercită, înainte de toate, polițistul trebuie să se legitimeze în faţa persoanelor cu care interacționează. Mai apoi, acesta are dreptul să ceară celor care încalcă legea sau există suspiciuni că plănuiesc să săvârşească o faptă care contravine legii, să se legitimeze pentru a le putea identifica. În cazul în care unele persoane pun în pericol viața celor din jur sau tulbură ordinea şi liniştea publică, polițistul trebuie să le conducă la sediul poliției. Dacă acestea se opun, organul de poliție va fi obligat să folosească forța pentru a le putea imobiliza.

Persoanele care pot ajuta la exercitarea şi îndeplinirea atribuțiilor poliției şi este necesară prezența acestora, sunt invitate la unitate şi sunt informate, în scris, despre motivul pentru care au fost chemate, dar şi scopul pe care îl au în rezolvarea unei situații.

Datorită relațiilor de cooperare dintre Poliția Română şi celelalte instituții, polițistii au obligația de a executa mandatele de aducere, de arestare şi de executare a pedepselor (Legea nr 218/ 2002, Art. 31, Alin. 1, Lit. d), în condițiile şi situațiile prevăzute de lege. Mai mult, aceştia au dreptul de a pătrunde în locuințele unor persoane în momentul comiterii unei infracțiuni sau în situația în care sunt urmăriți nişte infractori. În cazul autovehiculelor, polițiştii pot verifica bordurile pentru a se asigura că nu se transportă substanțe stupefiante sau alte mărfuri care să nu fie însoțite de acte. Persoanele şi bagajele pot fi şi ele verificate în situația în care există indicii concrete potrivit cărora $\mathrm{s}-\mathrm{a}$ comis sau se va comite o infracțiune sau ar putea avea loc atacuri teroriste.

Armamentul din dotare şi muniția necesară trebuie purtate de către polițist chiar dacă acesta poartă uniforma de serviciu sau este îmbrăcat în haine civile. Pentru a se pune în aplicare misiunile programate, polițistii trebuie să utilizeze autovehiculele din dotare, atât cele care au însemnele distinctive ale poliției, cât şi cele fără aceste simboluri.

Politịistul are dreptul să folosească atunci când consideră a fi necesar un alt mijloc de transport, excepție făcând cele care fac parte din corpului diplomatic Legea nr 218/ 2002, Art. 31, Alin. 1, Lit. i). Această situație este posibilă în cazul în care polițistul trebuie să ia anumite măsuri prevăzute de lege, nu pot fi exercitate printr-o altă modalitate şi nu pot fi amânate. Desigur, proprietarii pot face o cerere să li se achite anumite cheltuieli, aceste 
sume fiind suportate de către unitățile de poliție sau, în cazul în care există o persoană vinovată, aceasta va fi cea care le va suporta.

Ajutorul cetățenilor este bine-venit, polițiştii având dreptul să ceară sprijinul populației cu scopul de a prinde şi conduce la secția de poliție a celor care au săvârşit infracțiuni.

Exercitarea de către polițist a drepturilor pe care acesta le-a dobândit potrivit legii în vigoare, trebuie să nu depăşească limita legală şi nici să nu lezeze drepturile şi libertățile celorlalți din jurul.

Livrarea supravegheată este o metodă folosită destul de des de către polițişti pentru a putea prinde firul unei criminalități în serie. Astfel sunt trecute pe teritoriul țării droguri sau alte bunuri care, potrivit legii, nu ar avea dreptul de circulație, acest fapt având loc sub stricta supraveghere a procurorului, acesta şi controlând situația şi acțiunile care se efectuează. Scopul acestei metode este acela de descoperire a persoanelor care săvârş̧esc infracțiunile şi de a pune capăt în cele din urmă a criminalității organizate în speță.

Informațiile şi datele care sunt cunoscute de către polițişti în timpul exercitării atribuțiilor de serviciu trebuie să rămână confidențiale, aceştia neavând dreptul să le divulge unor alte persoane sau să le folosească cu alt scop decât cel prevăzut de lege.

Pentru a se putea restabili ordinea şi liniştea publică, în cazul în care persoanele care cauzează tulburarea refuză să coopereze sau să asculte de ordinele date de către polițişti, aceştia din urmă au dreptul să folosească şi alte mijloace care să le vină în ajutor precum: scuturi de protecție, bastoane de cauciuc, căşti cu vizor etc. Toate aceste obiecte pe care le folosesc, dar şi prin acțiunile lor, aceştia nu trebuie să pună în pericol viața persoanelor vinovate de situația în cauză sau a celor din jur, dar nici să le producă vătămări corporale grave.

Mijloacele pe care le pot folosi polițiştii în anumite situații, pot fi utilizate împotriva anumitor categorii de persoane:

a) „întreprind acțiuni care pun in pericol integritatea corporala, sănătatea sau bunurile altor persoane;

b) blochează, în afara condițiilor legii, căile publice de circulație, încearcă sa pătrundă, fără drept sau refuză să părăsească sediile autorităţilor publice, ale partidelor politice, ale instituţiilor si organizațiilor de interes public ori privat, periclitează în orice mod integritatea sau securitatea acestora ori a personalului sau tulbura desfăşurarea normala a activităţii; 

publice;

c) ultragiază persoanele cu funcții ce implică exercițiul autoritarii

d) se opun sau nu se supun, prin orice mijloace, îndeplinirii solicitărilor legale ale polițistului, numai daca exista o temere legitima ca prin acțiunile lor pot pune în pericol integritatea corporală sau viaţa polițistului” (Legea nr 218/ 2002, Art. 34, Alin. 2).

Acțiunile extreme care se desfăşoară în public trebuie să fie făcute prin aducerea la cunoștință a cetățenilor despre identitatea polițistilor prin strigarea cuvântului „Poliția!” (Legea nr 218/ 2002, Art. 34, Alin. 1). De asemenea, atunci când este necesar, polițistul este îndreptățit să folosească arme albe sau arme de foc. Utilizarea acestora din urmă trebuie făcută cunoscută în prealabil prin somația „Stai, stai că trag!” (Legea nr 218/ 2002, Art. 34, Alin. 1). In cazul legitimei apărări, polițistul nu este obligat să folosească somația precizată anterior.

În situațiile în care armamentul din dotare este folosit de către polițist în limitele prevăzute de lege şi îndeplineşte toate condițiile necesare, acesta nu este tras la răspundere pentru faptele sale, caracterul penal al faptei fiind înlăturat.

Polițistul nu are dreptul să folosească forța sau armele în cazul femeilor care prezintă semne vizibile de sarcină, persoanelor invalide sau copiilor. Această situație poate avea loc doar atunci când există dovezi că aceste persoane săvârşesc un atac armat sau prin care ar putea pune în pericol viața mai multor cetățeni.

Atunci când o persoană ameninţă că va distruge o clădire sau anumite bunuri care sunt de interes privat sau public, polițiştii pot să ia inițiativă şi să folosească forța pentru a îndepărta astfel de pericole.

În vederea îndeplinirii atribuțiilor de ordin profesional, personalul din cadrul Poliției Române are îndatorirea să colaboreze cu alte instituții şi să respecte drepturile şi libertățile persoanelor de pe teritoriul țării.

\section{I.2.2. Statutul poliţistului, adoptat prin Legea nr. 360/2002}

Statului polițistului, prind dispozițiile sale legale, oferă o definiție a polițistului: „Polițistul este funcționar public civil, cu statut special, înarmat, ce poartă, de regulă, uniformă şi exercită atribuțiile stabilite pentru Poliția Română prin lege, ca instituție specializată a statului” (Legea nr. 360/2002, Art. 2, Alin. 1).

În timpul exerciării acestei funcţii, polițistul îşi va asuma anumite riscuri, dar va avea şi unele obligații, atât faţă de cetăţeni, cât şi faţă de celealte instituții. Potrivit competenței sale, polițistul exercită autoritatea 
publică, dar numai în cadrul şi în legătură cu serviciul. Mai mult, îi este interzis acestuia să folosească funcția în anumite situații care prezintă scop personal.

Acțiunile şi atitudinea pe care le are un polițist trebuie să fie în interesul comunităţii şi să nu încalce sau să restrângă drepturile cetățenilor, care sunt prevăzute atât de dreptul intern, cât şi de cel internațional sau de tratatele la care România este parte.

Polițistul este răspunzător pentru modul în care îşi exercită atribuțiile şi felul în care acționează atunci când este în timpul serviciului. În cazul subordonaților, şefii ierarhici trebuie să îşi asume responsabilitatea pentru dispozițiile pe care le dau, dar şi pentru legalitatea acestora.

Se va ține cont de condițiile în care polițistul îşi desfăşoară activitatea, astfel acesta fiind recompensat prin acordarea, în anumite situaţii prevăzute de lege, unor drepturi compensatorii. Pentru ca un polițist să fie eliberat din funcție sau încadrat, se va ține seama de legislația în vigoare, respectându-se dispozițiile legale referitoare la calitatea de polițist.

Această profesie nu poate fi exercitată de orice persoană, ci doar de cea care, conform prevederilor legale, a obținut această calitate. Personalul Poliției Române poate proveni atât din rândul şcolilor cu un astfel de profil din țară, cât şi prin organizarea încadrărilor unor persoane din afara acestei sfere profesionale. Această din urmă calificare se poate realiza prin susținerea unui examen, sau în alte cazuri, prin participarea la un concurs.

Pentru a putea fi admise la o instituție de învățământ care aparține de Ministerul Administrației şi Internelor, orice persoană este admisă în cadrul concursului, neexistând criterii de selecție precum sexul, religia, naţionalitate etc.

Există anumite condiții care sunt impuse, iar pentru dobândirea statutului de polițist, acestea trebuie îndeplinite concomitent. Printre acestea, se numără cunoaşterea limbii române, nivelul fiind unul ridicat atât în privinţa abilităţilor de scriere, cât şi în privinţa discursului oral. Există şi un prag de vârstă (Legea nr. 360/2002, Art. 17, Alin. 1, Lit. d), persoanele care nu au vârsta de 18 ani neavând dreptul de a se înscrie la concurs. Pentru îndeplinirea atribuțiilor de serviciu, poliţistul trebuie să fie apt din punct de vedere medical, iar persoanele care au anumite afecțiuni ce influențează această capacitate fizică, dar şi mentală, nu vor putea să profeseze.

Datorită faptului că se pune un mare accent pe integritatea polițistului, cetățenii români care doresc să dobândească statutul de polițist trebuie să nu aibă antecedente penale şi nici să aparţină de vreo organizație 
care desfăşoară activități interzise de lege (Legea nr. 360/2002, Art. 17, Alin. 1, Lit. f). Având în vedere faptul că polițistul va reprezenta legea şi ordinea la nivel național, trebuie să aibă un nivel ridicat de integritate şi să nu fie compromis. Acesta va fi un exemplu pentru societate şi nu poate fi unul negativ. Mai mult, pentru că este liantul între societate şi celelalte instituții ale statului, nu are dreptul să facă parte dintr-un partid politic, astfel acesta urmărind asigurarea şi respectarea legii, nu opiniile sau doctrina unui anumit partid.

Odată dobândit statutul de polițist, în unele cazuri, acesta poate fi şi pierdut. În situația în care ,încetează raporturile de serviciu” se va pierde şi calitatea de polițist. De asemenea, când acesta este „transferat la alte autorităţi şi instituții publice" reprezintă o altă condiție care duce la încetarea calităţii de polițist (Legea nr. 360/2002, Art. 18).

Un polițist poate să îşi facă o carieră în acest domeniu, statutul pe care are oferindu-i oportunitatea să avanseze în funcție şi să se dezvolte pe plan profesional. Cariera unui polițist poate să fie strălucită, dar în spatele acesteia se află multe ore de muncă, stres şi multă dedicație.

Prin dobândirea statului de poliţist, se nasc şi anumite interdicții. Acestea sunt prezentate în art. 66 din Statutul polițistului şi i se îngrădesc acestuia unele drepturi. De exemplu, polițistul nu are dreptul să participe la greve, acesta trebuind să dea dovadă de integritate şi de imparțialitate. Odată aflat într-o tabără ar fi greu să fie obiectiv atunci când ar pune în aplicare legea. Cu toate că legea în vigoare îi dă dreptul să se folosească de forţă în anumite situații, acest fapt nu este posibil în orice condiții şi doar atunci când doreşte polițistul. De asemenea, având în vedere principiile acestei meserii, polițistul nu poate să intervină în numele unei persoane pentru a-i uşura situația nefavorabilă şi nici nu are dreptul să primească sau să solicite sume de bani sau alte alte bunuri. Acesta trebuie să îşi exercite atribuțiile de serviciu doar în conformitate cu legea şi cu spiritul acesteia, nesupunându-se altor persoane din afara instituției (dacă legea nu prevede altfel).

Polițistul nu trebuie să abuzeze de funcția pe care o are, dar nici să o folosească în interes personal. Onoarea acestuia nu trebuie să fie lezată prin acțiunile pe care le întreprinde, demnitatea trebuind a fi neştirbită. De asemenea, secretul profesional nu poate fi dezvăluit unor persoane care nu au drept de a fi informate în această situație. Referitor la exprimarea opiniilor pe care le au polițiştii, aceştia pot apărea în mass-media, dar nu în emisiuni cu caracter politic. In schimb, aceştia au dreptul de a-şi prezenta anumite 
cercetări sau raporturi pe care le-au făcut, dar să aibă legătură cu funcția pe care o dețin.

Incompatibilitatea polițistului nu trebuie trecută cu vederea, existând anumite situații prevăzute de lege în care acesta nu poate îndeplini concomitent şi o altă funcție. Potrivit art. 70, „Calitatea de polițist este incompatibilă cu deținerea şi/sau exercitarea oricărei alte funcții publice decât cea în care a fost numit, precum şi a demnităților publice alese" (Legea nr. 360/2002, Art. 70, Alin. 1). De asemenea, aceştia nu au dreptul să dețină o funcție într-o instituție publică, dar nici în cadrul regiilor autonome. Nici relațiile familiale nu sunt excluse din acest context, nefiind compatibile raporturile ierarhice dintre un soți polițişti. Dacă există un astfel de caz, unul dintre polițişti trebuie să ceară încetarea raporturilor în cauză în termen de 60 de zile.

Pentru o bună desfăşurare a activităţilor polițieneşti şi pentru a se ajunge la scopul urmărit, polițiştii trebuie să respecte legea şi normele legale care fac referire la statutul acestora, dar şi la legea de organizare şi funcționare a Poliției Române.

\section{I.2.3. Codul de etică şi deontologie al poliţistului}

Codul de etică şi deontologie al polițistului prezintă principiile şi regulile care ar trebui să fie urmate de către acesta în cariera sa, fiind „o datorie de onoare" (H. G. Nr. 991/2005, Art. 1) din partea poliţistului. Codul prevede reguli de conduită ce trebuie să fie respectate de către polițist în timp ce îşi exercită atribuțiile de serviciu. Mai mult, orice persoană este îndreptăţită să ceară poliţistului să respecte regulile prevăzute de acest cod (Stolojescu \& Radu, 2013).

Scopul Codului de etică şi deontologie al polițistului este acela de a asigura o conduită etică a acestuia. Formarea unei culturi profesionale stă la baza îndeplinirii obiectivului, dar şi educarea personalului în spiritul acesteia joacă un rol important.

Codul prezintă pe scurt principalele funcții (H. G. Nr. 991/2005, Art. 3) pe care le are Poliția Română, iar printre acestea se numără şi apărarea drepturilor şi libertăţilor persoanei. Legea nr. 218 din 2012 menționează atribuțiile pe care trebuie să le exercite personalul din cadrul Poliției Române, acestea regăsindu-se amintite şi de Codul de etică şi deontologie al poliţistului la articolul 3. Pe lângă apărarea persoanei şi a drepturilor acesteia, polițistul trebuie sigure ordinea şi liniştea publică, acest fapt putând fi realizat prin combaterea infracționalităţii şi pedepsirea persoanelor care au încălcat dispozițiile legale. 
Atribuțiile pe care le au polițiştii nu numai că au ca scop crearea unei atmosfere prielnice dezvoltării relaţiilor sociale şi economice, dar şi promovarea încrederii atât între cetățeni, cât şi între cetățeni şi instituții. Toate aceste acțiuni asigură democrația statului, neîngrădindu-se drepturile persoanelor, decât dacă legea nu prevede altfel.

Activitatea pe care o desfăşoară poliţia este realizată în interesul persoanelor şi a comunităților din care acestea fac parte. De asemenea, serviciul poliției vine şi în ajutorul instituțiilor statului prin respectarea dispozițiilor legale prevăzute atât de legea naţională, cât şi de cea internațională.

Misiunile îndeplinite de către poliție sunt subordonate instituțiilor competente prevăzute de lege, iar cooperarea cu Ministerul Public se realizează în limitele competenței conferite prin dispozițiile legale.

\section{Principii}

Conduita (H. G. Nr. 991/2005, Art. 6) pe care trebuie să o aibă o persoană din structura Poliției Române este guvernată de anumite principii care sunt prevăzute de Codul de etică şi deontologie al polițistului. Cu toate că poliția are ca sarcină aplicarea legii, acest fapt nu le dă dreptul polițiştilor să încalce legea, aceştia fiind ținuți să respecte atât prevederile legale, cât şi drepturile şi libertăţile persoanelor care se află pe teritoriul României.

Funcția pe care o au polițiştii nu le dă dreptul să fie mai presus de lege sau să nu o aplice conform dispozițiilor legale. Deoarece aceştia reprezintă într-o mare măsură legea, sunt obligaţi să se comporte şi să efectueze misiuni care nu contravin legii.

În exercitarea atribuțiilor de serviciu, polițistul nu are dreptul să discrimineze (H. G. Nr. 991/2005, Art. 6, Lit. b) unele persoane, îndatorirea lui fiind să le trateze pe toate cu egalitate. Religia, naționalitate, orientarea sexuală etc, nu ar trebui să constituie un criteriu care să influențeze modul în care poliţistul îşi face datoria. Polițistul are obligația de a oferi un tratament corect fiecărei persoane în parte, părerile sau credințele proprii neavând dreptul să îi afecteze misiunile efectuate în cadrul profesional.

Transparenţa (Constantin, 2012, p. 155) este un alt principiu care guvernează comportamentul unui polițist, acesta fiind deschis, în limitele legii, către societate. Pentru a putea îmbunătăți serviciile pe care le prestează, polițistul, având la baza experienţa sa în domeniu, poate să îşi exprime părerea cu privire la un subiect. Mai mult, polițistul atunci când îşi îndeplineşte atribuțiile de serviciu trebuie să trateze cu prioritate efectuarea serviciului în interesul comunității. 
Profesionalismul (H. G. Nr. 991/2005, Art. 6) este un alt principiu important după care se ghidează polițistul, acesta fiind reprezentat de măiestria şi pregătirea pe care a acumulat-o acesta de-a lungul timpului odată cu experiența sa şi punerea în practică a cunoştințelor sale. De asemenea, polițistul trebuie să acționeze responsabil şi să aplice corect noțiunile teoretice pe care le stăpâneşte.

Polițistul, în timpul desfăşurării activității pe care trebuie să o execute intră în contact cu numeroase date şi informații, iar acesta are obligația de a nu le divulga persoanelor care nu sunt îndreptăţite de lege sau să le folosească personal cu un alt scop. Acesta trebuie să asigure păstrarea acestor date şi informaţii, garantând astfel securitatea lor.

Ca orice altă persoană, polițistul trebuie ca prin comportamentul său să respecte persoanele din jurul său şi cele cu care va reacționa. Respectul se întinde şi asupra valorilor sociale, dar şi asupra normelor etice şi deontologice. Nici instituțiile cu care acesta interacționează nu trebuie să fie tratate fără respect de către organul de poliție, acesta menținându-şi o conduită conformă normelor sociale şi a legii.

Odată intrat în funcție, polițistul este dator să îşi exprime loialitatea faţă de instituție prin comportamentul său, dar şi faţă de valorile pe care aceasta le promovează. Acest fapt trebuie îndeplinit de către polițist prin acțiunile conştiente ale acestuia şi din proprie iniţiativă.

Integritatea (Constantin, 2012, p. 157) morală presupune însuşirea polițistului a unui comportament care să fie în concordanță cu regulile etice şi cele deontologice.

Polițistul are obligația de aşi îndeplini atribuțiile de serviciu conform competenței sale, dar are şi îndatorirea de a nu lăsa alte autorităţi sau alţi colegi să influențele negativ desfăşurarea activităţii sale.

\section{Exercitarea atribuțiilor}

Polițistul trebuie să respecte dispozițiile legale atunci când desfăşoară activități de serviciu, aceste dispoziții fiind prevăzute de către dreptul național sau cel internațional. De asemenea, polițistul trebuie să garanteze fiecărei persoane exercitarea neîngrădită a drepturilor pe care aceasta le are, respectând astfel principiul prezumției de nevinovăţie.

$\mathrm{Nu}$ este lipsită cooperare dintre polițişti şi cetăţeni, aceştia asigurând respectarea şi protejarea drepturilor şi libertăților fundamentale ale persoanei care sunt prevăzute atât de dreptul intern, cât şi de cel internaţional.

Polițistul care este în exercitarea atribuțiilor de serviciu este protejat de către instituție, cea din urmă oferindu-i sprijinul necesar. In timpul 
îndeplinirii atribuţiilor, polițistul este sprijinit de către autorităţile publice, acest fapt fiind efectual potrivit legii în vigoare.

\section{Utilizarea forței}

Polițistul are dreptul de a folosi forţa (Art. 31, Alin. 1, Lit. b) în îndeplinirea atribuțiilor doar în cazurile prevăzute de lege, acestea fiind expuse şi în Legea nr. 218 din 2002. Acțiunile care impun folosirea forței sunt acceptate doar în situații excepționale, respectându-se prevederile legale. Scopul acestora trebuie să fie unul legitim, şi forța să fie absolut necesară, neexistând alte mijloace pe care polițistul le-ar fi avut la îndemână la momentul desfăşurării acțiunii. De asemenea, aceste demersuri trebuie făcute cu respectarea anumitor principii consacrate de către diferitele texte legislative şi anume: necesitatea, gradualitatea şi proporţionalitatea (H. G. Nr. 991/2005, Art. 9, Alin. 2).

Cu ocazia îndeplinirii obiectivului legitim, exercitarea forței trebuie să înceteze. Cu toate că polițistul, în anumite situații, are dreptul să folosească acțiuni în forță, acesta nu trebuie niciodată să nu respecte demnitatea umană. Pentru a se restabili ordinea atunci când o persoană sau mai multe îl amenință şi este confruntat fizic, polițistul trebuie să nu se lase intimidat de situație şi să acționeze cu fermitate, dar să nu depăşească limitele legii.

\section{Deontologia măsurilor poliţieneşti}

Polițiştii au dreptul să ia unele măsuri (Legea nr. 218/2002, Art. 34, Alin. 1) prin care să priveze de libertate o persoană, iar acest fapt se realizează numai în măsura în care există indicii precum că o infracțiune a fost săvârşită sau urma a fi săvârşită. Pe lângă aceste semne, polițistul trebuie să respecte procedura legală şi nu trebuie să depăşească din perspectiva temporală perioada necesară înfăptuirii scopului inițial care a stat la baza luării măsurii.

Persoanele care sunt private de libertate în condiţiile prevăzute de lege trebuie să informate şi să li se aducă la cunoştinţă motivele pentru care le-a fost aplicată această măsură, dar şi să li se asigure exercitarea drepturilor pe care acestea le dobândesc în urma stabilirii calităţii pe care o au în acea situație.

Polițiştii se vor ocupa de monitorizarea stării de sănătate a persoanei care va fi supusă măsurii de privare de libertate, îi vor asigura condiţii igienice, de alimentație, dar şi siguranță. Pe perioada aplicării măsurii, organul de poliție trebuie să respecte întocmai procedura prevăzută de lege pentru astfel de situații. 


\section{Relaţia poliţistului cu diferite categorii de persoane}

Poliţistul, atât în timpul îndeplinirii atribuţiilor de serviciu, dar cât şi în afara acestora, are obligația de a ajuta persoana care a fost vătămată în urma comiterii unei infracțiuni. Organul de poliție va îndruma victima către instituțiile care îi vor putea oferi sprijinul necesar şi îi o va informa cu privire la mijloacele pe care le are la îndemână pentru a duce la soluționarea situației în care aceasta se află.

În cazul martorilor, polițiştii trebuie să îşi desfăşoare activitățile în conformitate cu competența cu care au fost învestiţi şi, de asemenea, să le respecte drepturile şi libertățile acestora. În timpul derulării acțiunilor, polițiştii trebuie să acorde o mai mare atenție anumitor persoane şi anume: „copiii, femeile, bătrânii şi persoanele cu handicap” (H. G. Nr. 991/2005, Art. 11, Alin. 3).

\section{Norme de conduită profesională a poliţistului}

Polițistul are datoria de a răspunde atunci când îi este adresată o solicitare, aceasta privind exercitarea profesiei, şi trebuie să nu dea dovadă de un comportament care ar putea pune la îndoială încrederea cetățenilor în poliție. De asemenea, acționează disciplinat în concordanță cu obiectivele instituției din a cărei structură face parte, înfăptuind toate îndatoririle care iau fost conferite odată cu funcția publică pe care a dobândit-o.

Amabilitatea trebuie să fie o caracteristică a polițistului, comportamentul acestuia fiind demn ferm şi politicos în acelaşi timp. Indiferent de situația în care va se va afla, poliţistul trebuie să fie calm şi să acționeze corect, fără ca ideile personale sau părerile acestuia să îi afecteze conduita. Trebuie să înţeleagă situaţia în faţa căreia este pus şi să găsească mijloace optime de rezolvare a problemelor care s-au ivit, încercând să nu dezavantajeze nici cel puțin o parte care face parte din conflict.

Pentru a putea fi recunoscut de către populație, polițistul trebuie ca pe lângă uniforma de serviciu, să poarte şi însemnele distinctive şi echipamentul din dotare, toate acestea fiind prevăzute de lege. În acest fel, populația va avea încredere în persoana care se prezintă ca a fi polițist, şi o va trata cu respect. De asemenea, acesta este obligat să se identifice şi să-şi facă cunoscută identitatea pe care o are în raport cu atribuțiile ce îi revin datorită funcției pe care o deține, reuşind astfel să ducă la realizarea interesului public.

În timpul serviciului, dar şi în afara acestuia, polițistul trebuie să protejeze şi să asigure nedivulgarea atât a secretul de serviciu, cât şi a celui de stat. Mai mult, informațiile şi datele pe care le va cunoaşte datorită 
funcției pe care o îndeplineşte, trebuie să fie confidențiale, neavând dreptul să le utilizeze în folos personal sau să le folosească abuziv. Nerespectarea confidențialităţii (Moris, 2011) şi păstrarea secretului vor fi pedepsite conform legii penale în vigoare.

Polițistul căruia i se aduce la cunoştinţă săvârşirea unor acte de tortură sau rele tratamente administrate unei persoane trebuie să ia de îndată măsurile necesare pentru îndepărtarea acestora. Îi este interzis să fie pasiv sau să acționeze în favoarea acestor tratamente inumane.

Autoritatea publică de care se bucură polițistul în funcție nu poate fi folosită abuziv, şi nici actele de corupție nu pot fi trecute cu vederea de către acesta. Îi este interzis polițistului să înfăptuiască acte de corupție prevăzute de legea penală cu scopul exercitării anumitor atribuții de serviciu care sunt prezente în fişa postului împotriva sau în beneficiul unei persoane. În cazul în care polițistul ia cunoştință de efectuarea anumitor acte de corupție care au loc în cadrul unității din care face parte sau din alte instituții, acesta are obligația de a sesiza superiorii săi sau alte organe competente.

Calitatea sau funcția pe care o are nu poate să fie folosită de către polițist în scop personal pentru a rezolva anumite probleme sau situații care nu au ca obiectiv interesul general al populaţiei. Persoanele care sunt de părere că le-a fost creat un prejudiciu sau a fost lezate de către polițişti prin misiunile pe care aceştia le-au efectuat, pot dace contestație (H. G. Nr. 991/2005, Art. 19, Alin. 4).

Conform art. 21, alin. (1) din Codul de etică şi deontologie al polițistului, „Polițistul este funcționarul public civil cu statut special, care exercită atribuțiile stabilite de lege pentru poliția română şi celelalte structuri polițieneşti din Ministerul Administrației şi Internelor.” Prin aderarea la Corpul Național al Polițiştilor, polițiştii pot să-şi promoveze interesele pe care aceştia le consideră a fi importante în desfăşurarea atribuţiilor de serviciu. De asemenea, prin aceeaşi metodă pot să îşi apere drepturile pe care le au atât ca persoană, dar şi pe cele pe care le-au dobândit după ce au fost investiți în funcție.

Acțiunile pe care le desfăşoară poliţistul trebuie să fie legale şi să se încadreze în legile din dreptul intern, dar să respecte şi pactele şi convenţiile internaționale la care România este parte. Acesta răspunde personal pentru „acțiunile, inacțiunile şi omisiunile sale” (H. G. Nr. 991/2005, Art. 23, Alin. 1), iar dacă trebuie să desfăşoare anumite activități ilegale, este obligat să comunice superiorilor situaţia în care se află, informarea fiind făcută şi 
verbal, dar şi în scris. În aceste condiții, atunci când polițistul refuză să execute ordinele, nu este sancţionat disciplinar.

Funcția de conducere care este exercitată de către un polițist, îl va obliga pe acesta să răspundă pentru ordinele pe care le va da celor aflaţi în subordinea lui.

În situația în care polițistul nu respectă dispozițiile legale instituite prin Codul de etică şi deontologie al poliţistului, acesta va răspunde disciplinar, civil sau penal, conform legislației care este în vigoare.

\section{Bibliografie}

Biroul Protocol Inspectoratul General al Poliției Române (2012). Poliția Română: Trecut-Prezent-Viitor. Revista de investigare a criminalitătuii, Anul V, Nr. 1, 6-

12. Retrieved from: http://www.cij.ro/revista/Revista 9.pdf

Constantin, E. C. (2013). Principalele Coordonate ale dezvoltării carierei personalului Poliției Române. Studii de securitate publică, II, 2(6), 42. Retrieved from: http://ssp.academiadepolitie.ro/revista/rev6.pdf

Dogaru, O. (2013). Deontologia polițistului în relație cu victimele infracțiunilor. Studii de securitate publică, II, 4(8), 51. Retrieved from: http://ssp.academiadepolitie.ro/revista/rev8.pdf

Druga, C., \& Stirbu, D. (2016). Instituția Poliției ca autoritate pentru asigurarea ordinii şi siguranței. Revista de investigare a criminalitatii, IX(1), 417-421. Retrieved from http://www.cii.ro/revista/Revista 21.pdf

Guvernul României, Hotarârea nr. 991 din 25/08/2005. Codul de etică şi deontologie al politistului. Publicat in Monitorul Oficial, Partea I nr. 813 din 07/09/2005.

INSCOP Research (2015a). Încrederea în institutii. Retrieved from http://www.inscop.ro/septembrie-2015-increderea-in-institutii/

INSCOP Research (2015b). Increderea in institutii. Retrieved from http://www.inscop.ro/decembrie-2015-incredere-institutii/

INSCOP Research (2016). Increderea in institutiii. Retrieved from http://www.inscop.ro/aprilie-2016-increderea-in-institutii/

Legea nr. 218 din 2002 privind organizarea si functionarea Politiei Romane. Publicata in Monitorul Oficial nr. 305 din 9 mai 2002. Retrieved from http://legislatie.resurse-pentru-democratie.org/legea/218-2002.php

Legea nr. 360 din 2002 privind Statutulpolitistului. Publicata in Monitorul Oficial nr. 440 din 24 iunie 2002. Retrieved from http://legislatie.resurse-pentrudemocratie.org/legea/360-2002.php

Manta, A. M. (2016). Ordinea şi siguranța publică în sistem integrat. Revista de investigare a criminalitatii, $I X(1), 612-619$. Retrieved from http://www.cij.ro/revista/Revista 21.pdf

Moris, C. (2011). A Cross-National Study on Public Confidence in Police. Boston (Massachusetts): Northeastern University. 
Niţă, N. (2012). Particularităţile implementării sistemului de management al calității în Poliția Română. Revista de investigare a criminalitătiii, $V(2), 15-23$. Retrieved from http://www.cij.ro/revista/Revista 11.pdf

Poliția Română (2014). Scurt istoric. Retrieved from https://www.politiaromana.ro/ro/informatii-generale/scurt-istoric

Rotaru, C. (2013). Unele aspecte privitoare la activitatea de prevenire a criminalității. Studii de securitate publică, Vol. II, Nr. 1(5), 10. Retrieved from http://ssp.academiadepolitie.ro/revista/rev5.pdf

Stolojescu, G., \& Radu, S. (2013). Principiile etice şi juridice care stau la baza exercitării profesiei de politist [Legal And Ethical Principles Underlying The Police Duty]. Studii de securitate publică, Vol. II, Nr. 4(8), 167-177.

Retrieved from http://ssp.academiadepolitie.ro/revista/rev8.pdf

Ştefan, C-E. (2013). The Police Life in The Society. Studii de securitate publică, II, 3(7).

Retrieved from http://ssp.academiadepolitie.ro/revista/rev7.pdf

Torje, D-C. (2015). Polițistul - Oglinda societăţii. Revista de investigare a criminalității, VIII, Nr. special, I., 31-38. Retrieved from http://www.cij.ro/revista/Revista 18.pdf 